\title{
PELATIHAN MASYARAKAT PEDULI HIPERTENSI DI DESA MOJOKRAPAK KECAMATAN TEMBELANG KABUPATEN JOMBANG
}

\author{
Community Training Hypertension In The Village Mojokrapak District Declines Of \\ Jombang District
}

\author{
Miftachul Huda, Rini Hayu Lestari, Rosa Purwanti \\ STIKES PEMKAB JOMBANG \\ miftachulhuda@gmail.com
}

\begin{abstract}
ABSTRAK
Hipertensi sering kali disebut sebagai pembunuh gelap (silent killer) karena termasuk yang mematikan tanpa disertai dengan gejala-gejalanya lebih dahulu sebagai peringatan bagi korbannya .Permasalahan Mitra dan Solusi Jumlah Kasus Hipertensi yang didiagnosis oleh tenaga kesehatan di Di Desa Mojokrapak Kecamatan Tembelang Jombang Mengingat kasus Hipertensi lebih banyak didapatkan pada wanita dan tingginya kasus Hipertensi pada lansia. Metode yang digunakan adalah dengan melihat prosentase dari kuesioner pre dan post yang dibagikan ke peserta apakah adanya peningkatan setelah diberikan pelatihan tentang kepedulian tentang hipertensi. Pelaksanan kegiatan pengabdian masyarakat ini dilakukan oleh 3 (tiga) orang tim pengabdi dengan pokok bahasan yang disampaikan mengenai: 1. Teori hipertensi 3. Latihan cara tensi ke kader 3.Praktek pemeriksaan tensi. Kegiatan yang diawali dengan ceramah dan demonstrasi ini kemudian dilanjutkan latihan. Dari kegiatan latihan tampak bahwa peserta sangat antusias mengikuti kegiatan. Acara kemudian dilanjutkan sesi tanya jawab. Berbagai pertanyaan diajukan secara antusias oleh para peserta dalam sesi tanya jawab. Kegiatan pengabdian masyarakat dilihat dari jumlah peserta yang mengikuti dapat dikatakan berhasil/ sukses. Adanya interaksi Tanya jawab dari peserta yang antusias maka dapat disimpulkan bahwa tujuan kegiatan ini dapat tercapai. Dan latihan /praktek terapi tertawa peserta dapat mengulangi lagi apa yang telah dipraktekkan oleh tim pengabdian masyarakat.
\end{abstract}

Kata Kunci : hipertensi, lansia, pelatihan

\begin{abstract}
Hypertension is often referred to as a silent killer because it includes a lethal without accompanying symptoms first as a warning to the victim. Problems Partner and Solution Number of Hypertension Cases diagnosed by health personnel in In Village Mojokrapak District Jembranang Tembelang Given cases of hypertension more prevalent in women and high cases of hypertension in elderly. The method used is to see the percentage of pre and post questionnaires distributed to participants whether there is improvement after training on concern about hypertension. The implementation of community service activities is done by 3 (three) team of devotees with the subjects presented about: 1. Hypertension Theory 3. Exercise how to tension to cadres 3. Practice of tension examination. Activities that begin with lectures and demonstrations are then continued with practice. From the training activities it appears that the participants are very enthusiastic to follow the activities. The event then continued with question and answer session. Questions were asked enthusiastically by the participants in the question and answer session. Community service activities seen from the number of participants who follow can be said successful / successful. The existence of question and answer interactions from enthusiastic participants it can be concluded that the purpose of this activity can be achieved. And practice / therapy therapy laugh participants can repeat again what has been practiced by community service team.
\end{abstract}

Keywords: hypertension, elderly, training

\section{PENDAHULUAN}

Hipertensi sering kali disebut sebagai pembunuh gelap (silent killer) karena termasuk yang mematikan tanpa disertai dengan gejala- gejalanya lebih dahulu sebagai peringatan bagi korbannya. Menurut WHO batas normal tekanan darah adalah $120-140 \mathrm{mmHg}$ tekanan sistolik dan $80-90 \mathrm{mmHg}$ tekanan 
diastolik.Seseorang dinyatakan mengidap hipertensi bila tekanan darahnya >140/90 $\mathrm{mmHg}$.Tekanan darah yang tinggi merupakan salah satu faktor resiko untuk stroke, serangan jantung, gagal jantung, aneurisma arterial, dan merupakan penyebab utama gagal jantung kronis (Tekanan Darah Tinggi,2012).Dengan demikian hipertensi adalah suatu keadaan dimana seseorang mengalami peningkatan tekanan darah di atas normal yaitu > 140/90 $\mathrm{mmHg}$.

Prevalensi Hipertensi di Indonesia berdasarkan data Riset Kesehatan Dasar (Riskesdas 2013) sebesar 25,8\%. Prevalensi Hipertensi di Indonesia yang terdiagnosis tenaga kesehatan sebesar 9,4 persen. Hipertensi merupakan salah satu penyakit yang memiliki fenomena gunung es, yaitu angka kesakitan (morbiditas) yang tidak diketahui lebih banyak dibandingkan dengan angka morbiditas yang diketahui oleh pusat pelayanan kesehatan (Singh, 2014). Terdapat 13 provinsi di Indonesia dengan prevalensi penderita Hipertensi melebihi angka nasional, salah satunya adalah di Provinsi Jawa Timur $(26,2 \%)$. Berbagai faktor risiko telah dihubungkan dengan terjadinya Hipertensi. Hipertensi didapatkan lebih tinggi pada orang orang yang mempunyai kebiasaaan merokok $(41,1 \%)$, aktifitas fisik kurang (55,5\%), obesitas (45,3\%), tinggi lingkar pinggang $(85,4 \%)$ dan konsumsi garam yang tinggi $(83,5 \%)$, konsumsi buah yang kurang $(73,2 \%)$, riwayat keluarga menderita Hipertensi $(64,6 \%)$ dan riwayat keluarga stroke / CVD $(50,6 \%)$ (Shiekh, 2015). Sebagian besar kasus hipertensi tidak terkontrol ditemukan pada masyarakat dengan umur lebih dari 60 tahun (Chataut, 2012). Berdasarkan jenis kelamin tahun 2007 maupun tahun 2013 prevalensi hipertensi perempuan lebih tinggi dibanding laki-laki. Hubungan antara Hipertensi dengan tingkat sosial ekonomi telah diteliti oleh Sihombing. Pada penelitian tersebut berdasarkan status ekonomi responden diketahui bahwa status ekonomi tinggi terlihat relatif berisiko hipertensi dibandingkan dengan status ekonomi rendah $(\mathrm{OR}=1,05 ; 95 \% \mathrm{CI}$, 1,01-1,09) (Sihombing, 2010). Namun saat ini Hipertensi bersama dengan penyakit kardiovaskuler lainnya banyak berkembang di masyarakat miskin dengan sosial ekonomi rendah. Prevalensi Hipertensi cenderung lebih tinggi pada kelompok pendidikan lebih rendah dan kelompok tidak bekerja, kemungkinan akibat ketidaktahuan tentang pola makan yang baik (Riskesdas, 2013). Prevalensi Hipertensi pada masyarakat miskin dan sangat miskin sebesar 68,5\%. Ditemukannya hubungan yang bermakna antara status ekonomi, dengan kejadian Hipertensi (Lely, 2009).

Mengingat tingginya angka kejadian Hipertensi yang ditemukan di sarana pelayanan kesehatan dan tingginya kasus hipertensi terutama pada wanita yang belum terjangkau pelayanan kesehatan maka perlu lebih memprioritaskan program pencegahan dan penanggulangan Hipertensi di masyarakat terutama pada wanita yang belum memasuki masa usia lanjut/ lansia ( $<60$ tahun) di Kecamatan Sukarame. Kegiatan ini merupakan model pembinaan bagi ibu ibu yang belum berusia 60 tahun (lansia) untuk menambah wawasan dan pemahaman wanita tentang penyakit Hipertensi. Kegiatan ini akan meningkatkan kepedulian masyarakat dalam pencegahan penyakit Hipertensi. Pelaksanaan kegiatan Ipteks Tepat Guna bagi Masyarakat (ITGbM) dilakukan bekerja sama dengan 2 (dua) posyandu di Kecamatan Sukarame yaitu Posyandu Edelwess dan Posyandu Dahlia. Hasil pertemuan dan diskusi dengan mitra disepakati upaya pencegahan penyakit Hipertensi akan dilakukan dengan strategi pelatihan masyarakat peduli Hipertensi yang bertujuan untuk (1) meningkatkan pemahaman ibu ibu tentang penyakit Hipertensi (2) Meningkatkan kemampuan ibu ibu dalam mencegah penyakit Hipertensi (3) Peningkatan keterlibatan perguruan tinggi dalam menyusun buku saku dan leaflet tentang pencegahan Hipertensi.

Permasalahan Mitra dan Solusi Jumlah Kasus Hipertensi yang didiagnosis oleh tenaga kesehatan di Di Desa Mojokrapak Kecamatan Tembelang Jombang Mengingat kasus Hipertensi lebih banyak didapatkan pada wanita dan tingginya kasus Hipertensi pada lansia, maka perlu dilakukan kegiatan pelatihan masayarakat peduli Hipertensi pada ibu-ibu 
yang belum memasuki masa lansia ( $<60$ tahun) agar dapat melakukan upaya pencegahan terhadap penyakit Hipertensi.

Dan melibatkan Kader Di Desa Mojokrapak Kecamatan Tembelang Jombang sebagai mitra untuk melanjutkan program peduli hipertensi.

Sasaran dalam pengabdian masyarakat ini adalah lansia Dan Keluarga Lansia dengan hipertensi.pelaksanaan ini melibatkan mitra dari puskesmas yaitu bidan desa dan kader desa Di Desa Mojokrapak Kecamatan Tembelang Jombang

\section{METODE}

Metode yang digunakan adalah dengan melihat prosentase dari kuesioner pre dan post yang dibagikan ke peserta apakah adanya peningkatan setelah diberikan pelatihan tentang kepedulian tentang hipertensi. Pengabdian Masyarakat dilakukan bekerja sama dengan kader- kader di Di Desa Kali Kejambon Kecamatan Tembelang Jombang . Hasil pertemuan dan diskusi dengan mitra disepakati upaya pencegahan penyakit Hipertensi akan dilakukan dengan strategi pelatihan masyarakat peduli Hipertensi. Sasaran kegiatan ini adalah ibu ibu yang belum berusia 60 tahun dengan harapan dapat melakukan upaya pencegahan penyakit Hipertensi sebelum lansia,

\section{HASIL}

Kegiatan pengabdian masyarakat yang dilaksanakan dengan kader dan peserta berjalan dengan baik dan lancar. Pertemuan tatap muka dengan metode ceramah dan demonstrasi, dilanjutkan latihan/praktek. Kegiatan ini dilaksanakan sehari yaitu pada hari Senin tanggal 19 Februari 2018 dari pukul 07.3013.00 WIB. Peserta kegiatan berjumlah 30 orang dan lokasi penyelenggaraan di desa mojokrapak tembelang jombang.

Pelaksanan kegiatan pengabdian masyarakat ini dilakukan oleh 3 (tiga) orang tim pengabdi dengan pokok bahasan yang disampaikan mengenai: 1. Teori hipertensi 3. Latihan cara tensi ke kader 3.Praktek pemeriksaan tensi. Kegiatan yang diawali dengan ceramah dan demonstrasi ini kemudian dilanjutkan latihan. Dari kegiatan latihan tampak bahwa peserta sangat antusias mengikuti kegiatan. Acara kemudian dilanjutkan sesi tanya jawab. Berbagai pertanyaan diajukan secara antusias oleh para peserta dalam sesi tanya jawab.

\section{PEMBAHASAN}

Hasil kegiatan Pengabdian masyarakat ini secara garis besar mencakup beberapa komponen sebagai berikut: 1. Keberhasilan target jumlah peserta 2. Ketercapaian tujuan pengabdian masyarakat ini 3. Ketercapaian target materi yang telah direncanakan 4 . Interaksi Tanya jawab. Dalam pelaksanaannya, kegiatan ini diikuti oleh 30 orang peserta. Dengan demikian dapat dikatakan bahwa target peserta dapat tercapai. Ini menunjukkan bahwa kegiatan pengabdian masyarakat dilihat dari jumlah peserta yang mengikuti dapat dikatakan berhasil/ sukses. Adanya interaksi Tanya jawab dari peserta yang antusias maka dapat disimpulkan bahwa tujuan kegiatan ini dapat tercapai. Dan latihan /praktek terapi tertawa peserta dapat mengulangi lagi apa yang telah dipraktekkan oleh tim pengabdian masyarakat.

\section{KESIMPULAN DAN SARAN KESIMPULAN}

Kegiatan Pengabdian Masyarakat ini dapat diselenggarakan dengan baik dan berjalan dengan lancar sesuai dengan rencana kegiatan yang telah disusun. Kegiatan ini mendapat sambutan sangat baik terbukti dengan keaktifan peserta dengan tidak meninggalkan tempat sebelum waktu pelatihan berakhir.

\section{SARAN}

Adanya kegiatan lanjutan yang berupa pengabdian Masyarakat sejenis, Petugas kesehatan lebih optimal melibatkan kader dalam penjaringan masyarakat yang mengalami hipertensi dari segala umur., Masyarakat lebih mengetahui tentang apa itu hipertensi dan tanda bahayanya baik dari segala umur,jenis kelamin, dll.

\section{DAFTAR PUSTAKA}


Aziza, Lucky. 2007. Hipertensi The Silent Killer. Jakarta: Yayasan Penerbitan Ikatan Dokter Indonesia

Udjianti, Wajan. 2011. Keperawatan Kardiovaskular. Jakarta: Salemba Medika. Kowalski, Robert. 2010. Terapi Hipertensi: Program 8 minggu Menurunkan Tekanan Darah Tinggi. Alih Bahasa: Rani Ekawati. Bandung: Qanita Mizan Pustaka

Astuti, 2012. Hubungan Hipertensi dan Stroke. Universitas Negeri Surakarta

Depkes RI, 2012. Masalah Hipertensi di Indonesia. Kementrian Kesehatan RI, Jakarta

Mancia, Guissepe, dkk, 2013. 2013 ESH/ESC Guidelines For The Management of Arterial Hypertension. Journal of Hypertension

Herwati,Wiwi sartika Terkontrolnya Tekanan Darah Penderita Hipertensi Berdasarkan Pola Diet Dan Kebiasaan Olah Raga Dipadang Tahun 2011 Jurnal Kesehatan Masyarakat, September 2013 - Maret 2014, Vol. 8, No. 1 file:///C:/Users/Operator\%20B/Downloa ds/118-241-1-SM.pdf. Di Akses Tanggal 10 Oktober 2017 